\title{
PENGEMBANGAN PENDIDIKAN KARAKTER MELALUI KANTIN KEJUJURAN
}

\author{
Arrahim \\ FKIP Universitas Muhammadiyah Malang, Indonesia \\ Email: arrahim@gmail.com
}

\begin{abstract}
The character of nations that now becomes the focus on various life aspects is honesty. Now, the value of honesty is used as an example of a precious and costly thing. The weak value of honesty in school, like cheating and lying to a teacher, will negatively affect the education process and the learning outcome. The value of honesty can be improved through self-service canteen, so the material or main topic of the lesson in the subject can be immediately implemented. Self-service canteen is one of the effective strategies that enable the students to learn and practice implementing the values of anti-corruption and as a forum for the education of the prospective anti-corruption national leader. The study conducted at SMA Negeri 8 Malang discussed (1) the implementation of character-building education development through the management of self-service canteen at SMA Negeri 8 Malang, (2) the description of the obstacles found in the implementation, (3) the description of solutions to reduce the obstacles during the implementation. This study used a descriptive qualitative approach, in which the researcher was directly involved to find out information related to the title of the study. The data were collected through observation, interviews, and documentation. In addition, the informants were the headmaster, vice headmaster for student affairs, the coordinator of anti-corruption education/self-service canteen, civics teacher, and students of SMA Negeri 8 Malang. Based on the research finding, the conclusion was obtained as follows: (1) Anti-corruption education/self-service canteen was launched 6 months ago. The concept was simple by providing snacks and beverages. The food was displayed on a table with is the price tag. There was a box for money from the box. The management mechanism was fully offered to the students, under the guidance of the management coordinator self-service canteen. (2) There was not any available change. Consequently, some students who owed forgot to pay. (3) The coordinator of self-service canteen gave instructions and guidance to the students continuously during the flag ceremony and the class activity, inserted the lesson materials about honesty, fairness, simplicity, struggle, and others.
\end{abstract}

Keywords: Development; Character Building Education; Self-service Canteen.

\section{PENDAHULUAN}

Asmani (2012) globalisasi sudah menyebar di penjuru dunia, bahkan sampai daerah terpencil sekalipun. Masuk kerumahrumah, membombardir pertahanan moral dan agama, sekuat apapun dipertahankan. Televisi, Internet, Koran, Handphone dan lain-lainnya adalah media informasi dan komunikasi yang berjalan dengan cepat dan menggulung sekat-sekat tradisional yang selama ini dipegang kuat-kuat.

Moralitas berkurang. Sesuatu yang dahulu dianggap tabu, sekarang menjadi biasa-biasa saja. Cara berpakaian, berinteraksi dengan lawan jenis, menikmati hiburan malam, kekerasan antar pelajar, korupsi di mana-mana, kejujuran menjadi sesuatu yang sangat langkah, mengonsumsi narkoba menjadi tren dunia modern yang sulit ditanggulangi.

Globalisasi menyediakan seluruh fasilitas yang dibutuhkan manusia, negatif maupun positif. Banyak manusia yang terlena dengan menuruti seluruh keinginannya apalagi memiliki rezeki melimpah dan lingkungan kondusif.

Akhirnya karakter anak bangsa berubah menjadi rapuh, mudah diterjang ombak, terjerumus dalam tren budaya yang negatif, dan tidak memikirkan 
akibat yang ditimbulkan. Prinsip-prinsip moral, budaya bangsa, dan perjuangan hilang dari karakteristik mereka. Inilah yang menyebabkan dedikasi moral serta hilangnya kreativitas dan produktivitas bangsa. Sebab, ketika karakter suatu bangsa rapuh. Maka semangat berkreasi dan berinovasi dalam kompetensi yang ketat akan mengendur. Kemudian dikalahkan oleh semangat hedonisme yang instan dan menenggelamkan.

Di sinilah pentingnya menanamkan Pendidikan Anti Korupsi/Kantin Kejujuran yang bertujuan untuk mencetak anak bangsa yang mempunyai karakter yang diharapkan bangsa itu sendiri. Salah satu yang diterapkan sekolah secara intensif dengan keteladanan, kearifan, dan kebersamaan, baik dalam program intrakurikuler maupun ekstrakurikuler sebagai pondasi kokoh yang bermanfaat bagi masa depan anak didik. Pembangunan pendidikan karakter ini banyak dilupakan oleh pihak sekolah selama ini. Mereka terlalu fokus pada target Ujian Nasional (UN) dan kompetensi akademis lainnya. Kecerdasan intelektual dianakemaskan, sedangkan kecerdasan emosional dan spiritual dimarginalkan. Hasilnya, kecerdasan intelektual hancur karena rapuhnya kecerdasan emosional dan spiritual.

Virus kesadaran pendidikan karakter dari sekolah diharapkan menyebar kepada: Sekolah, guru, keluarga, masyarakat, media massa, dan seluruh elemen bangsa ini. Sehingga terjadi sinergi kekuatan dalam membangun bangsa ini demi lahirnya kader-kader masa depan yang berkarakter, serta berkepribadian kuat dan cermat.

Penelitian ini dilakukan dengan tujuan menularkan virus pendidikan karakter terhadap semua pihak yang peduli pada kesuksesan bangsa ini dalam membangun karakter generasi mudanya. Terutama di lembaga pendidikan sebagai kawah candradimuka dalam proses kematangan intektual, emosional, dan spiritual anak didik.
Sirajuddin (dalam Asmani, 2012), mengemukakan bahwa istilah karakter baru dipakai secara khusus dalam konteks pendidikan pada akhir abad ke-18 dan pencetusnyaadalahFW.Foerster. Terminologi ini mengacu pada sebuah pendekatan idealisspiritualis dalam pendidikan yang juga dikenal dengan teori pendidikan normatif. Lahirnya pendidikan karakter merupakan sebuah usaha untuk menghidupkan kembali pedagogi ideal-spiritual yang sempat hilang diterjang gelombang positifisme yang dipelopori oleh filsuf Prancis, Auguste Comte.

Karakter merupakan titian ilmu pengetahuandanketerampilan.Pengetahuan tanpa landasan kepribadian yang benar akan menyesatkan, dan keterampilan tanpa kesadaran diri akan menghancurkan. Karakter itu akan membentuk motivasi yang dibentuk dengan metode dan proses yang bermartabat. Karakter bukan sekedar penampilan lahiriah, melainkan mengungkapkan secara implisit hal-hal yang tersembunyi. Oleh karenanya, orang mendefinisikan karakter sebagai "siapa anda dalam kegelapan?". Karakter yang baik mencakup pengertian kepedulian, tindakan berdasarkan nilai-nilai etika, serta meliputi nilai aspek kognitif, emosional, dan perilaku dari kehidupan moral.

Asmani (2012), mengemukakan bahwa tujuan pendidikan karakter adalah penanaman nilai dalam diri siswa dan pembaruan tata kehidupan bersama yang lebih menghargai kebebasan individu. Tujuan jangka panjangnya tidak lain adalah mendasarkan diri pada tanggapan aktif kontekstual individu atas impuls natural sosial yang diterimanya. Pada gilirannya semakin mempertajam visi hidup yang akan diraih lewat proses pembentukan diri secara menerus (on going formation). Tujuan jangka panjang ini merupakan pendekatan dialektis yang semakin mendekatkan dengan kenyataan yang ideal. Melalui proses refleksi dan interaksi secara terus-menerus antara idealisme, 
pilihan sarana, dan hasil langsung yang dapat dievaluasi secara objektif.

Pendidikan karakter juga bertujuan meningkatkan mutu penyelenggaraan dan hasil pendidikan di sekolah yang mengarah pada pencapaian pembentukan karakter dan akhlak mulia peserta didik secara utuh, terpadu, dan seimbang sesuai dengan standar kompetensi lulusan. Melalui pendidikan karakter, diharapkan peserta didik mampu secara mandiri meningkatkan dan menggunakan pengetahuannya, mengaji dan menginternalisasi serta mempersonalisasi nilai-nilai karakter dan akhlak mulia sehingga terwujud dalam perilaku sehari-hari.

Pendidikan karakter pada tingkat institusi mengarah pada pembentukan budaya sekolah, yaitu nilai-nilai yang melandasi perilaku, tradisi, kebiasaan sehari-hari dan simbol-simbol yang dipraktikkan oleh semua warga sekolah dan masyarakat sekitarnya. Budaya sekolah merupakan ciri khas, karakter atau watak, dan citra sekolah tersebut di mata masyarakat luas.

Sebuah buku yang berjudul Emotional Intelligence And School Success (Zins, 2001), mengompilasikan berbagai hasil penelitian tentang pengaruh positif kecerdasan emosi anak terhadap keberhasilan di sekolah. Dikatakan bahwa ada sederet faktor-faktor risiko penyebab kegagalan anak di sekolah. Faktor-faktor risiko yang disebutkan ternyata bukan terletak pada kecerdasan otak. Akan tetapi pada karakter, yaitu rasa percaya diri, kemampuan bekerja sama, kemampuan bergaul, kemampuan berkosentrasi, rasa empati, dan kemampuan berkomunikasi.

Hal itu sesuai dengan pendapat Goleman, tentang keberhasilan seseorang di masyarakat. Menurutnya, $80 \%$ keberhasilan seseorang di masyarakat dipengaruhi oleh kecerdasan emosi, dan hanya 20\% ditentukan oleh kecerdasan otak (IQ). Anak-anak yang mempunyai masalah dalam kecerdasan emosinya akan mengalami kesulitan dalam belajar, bergaul, dan tidak dapat mengontrol emosinya. Anak-anak yang bermasalah ini sudah tidak dapat melihat sejak usia prasekolah, dan kalau tidak ditangani akan terbawa sampai usia dewasa. Sebaliknya, para remaja yang berkarakter akan terhindar dari masalah-masalah umum yang dihadapi oleh remaja. Seperti kenakalan, tawuran, narkoba, miras, perilaku seks bebas, dan lain sebagainya.

Beberapanegarayangtelahmenerapkan pendidikan karakter sejak pendidikan dasar di antaranya adalah Amerika Serikat, Jepang, Cina, dan Korea. Hasil penelitian di negaranegara lain menyatakan bahwa implementasi pendidikan karakter yang tersusun secara sistematis berdampak positif pada pencapaian akademik. Seiring dengan sosialisasi tentang relevansi pendidikan karakter ini, semoga dalam waktu dekat tiap sekolah bisa segera menerapkannya. Agar nantinya lahir generasi bangsa yang cerdas dan karakter sesuai dengan nilai-nilai luhur bangsa dan agama.

\section{METODE}

Penelitian ini menggunakan pendekatan kualitatif.Karenapermasahanyangdibahasdalam penelitian ini tidak berkenaan dengan angkaangka. Tetapi mendeskripsikan, menguraikan dan menggambarkan tentang pengembangan pendidikan karakter melalui Kantin Kejujuran di SMANegeri 8 Malang. Ide dari penelitian ini, yaitu supaya kita dapat mengadakan pengamatan tentang sesuatu fenomena atau memperoleh hasil. Penelitian kualitatif adalah prosedur penelitian yang menghasilkan deskriptif berupa kata-kata atau tulisan dari orang atau perilaku yang diamati, Bogdan dan Tylor (dalam Zuriah, 2009).

Moleong (2011), mengemukakan bahwa penelitian kualitatif adalah yang menggunakan pendekatan naturalistik untuk mencari dan menemukan pengertian atau pemahaman tentang fenomena dalam suatu latar yang berkonteks khusus.

Instrumen penelitian merupakan alat bantu bagi Peneliti dalam mengumpulkan data. Kualitas instrumen akan membantu 
kualitas data yang terkumpul. Ungkapan "Garboge tool garbage result", merupakan hubungan antara instrumen dengan data. Oleh karena itulah, menyusun instrumen bagi kegiatan penelitian merupakan langkah penting yang harus dipahami secara tepat oleh peneliti, Arikunto (dalam Zuriah, 2009). Hal senada juga diungkapkan oleh Margono (dalam Zuriah 2009), mengemukakan bahwa pada umumnya penelitian akan berhasil dengan baik apabila banyak yang menggunakan instrumen. Arikunto (2010), mengemukakan bahwa instrumen yang baik harus memenuhi dua persyaratan penting, yaitu valid dan reliabel.

Zuriah (2009), mengemukakan bahwa analisis data dalam penelitian merupakan suatu kegiatan yang sangat penting dan memerlukan ketelitian serta kekritisan dalam penelitian. Analisis data melibatkan pengerjaan data, organisasi data, pemilihan menjadi satuan-satuan tertentu, sintesis data, pelacakan pola, penemuan hal-hal yang penting dan dipelajari, serta penentuan yang harus dikemukakan kepada orang lain. Sehingga pekerjaan analisis data dalam penelitian kualitatif bergerak dari penulisan deskriptif kasar sampai pada produk penelitian. Dengan kata lain, dalam penelitian kualitatifberdasarkan kurung waktunya, data yang dianalisis pada saat pengumpulan data dan setelah selesai pengumpulan data.

Dari hasil observasi, wawancara, serta dokumentasi Peneliti dengan informasi Kepala Sekolah, Waka Kesiswaan, Koordinator Pendidikan Anti Korupsi/Kantin Kejujuran, Guru PKn dan Siswa SMA Negeri 8 Malang. Maka akan disusun dan dianalisis sehingga dapat dibuat kesimpulan.

Untuk menguji validitas data dalam penelitian ini dilakukan pemeriksaan yang didasarkan pada kriteria tertentu. Menurut Moleong (2011), ada 10 kriteria dalam pemeriksaan data, yaitu: (a) kredibilility (kepercayaan), yaitu kriteria untuk memenuhi nilai kebenaran dari data dan informasi yang dikumpulkan. Artinya, hasil penelitian harus dapat dipercaya oleh semua pembaca secara kritis dan responden sebagai informan untuk hasil penelitian yang memenuhi kredibilitas; (b) Keteralihan, yaitu kriteria untuk memenuhi bahwa hasil penelitian yang dilakukan dalamkonteks tertentu dapat diaplikasikan atau ditransfer pada konteks atau setting lain yang dimiliki tipologi yang sama; (c) Kebergantungan, yaitu kriteria yang digunakan untuk menilai apakah proses penelitian kualitatif bermutu atau tidak, dengan mengecek; apakah peneliti sudah cukup hati-hati, apakah membuat kesalahan dalam mengonseptualisasikan rencana penelitiannya, pengumpulan data dan penginterpretasiannya. Teknik terbaik yang digunakan untuk langkah ini adalah dengan dependability audit, yaitu meminta independen auditor untuk meriview aktivitas peneliti. Pada penelitian ini, untuk menghindari kesalahan yang ditimbulkan dari peneliti sendiri maka dibutuhkan orang lain sebagai auditornya. Informasi yang diperoleh dari informan di SMA Negeri 8 Malang, meliputi Kepala Sekolah, Waka Kesiswaan, Koordinator Pendidikan Anti Korupsi/Kantin Kejujuran, Guru PKn, dan siswa serta berupa data mentah dan ke urutan data dicek kembali dan di review dengan data yang telah ada oleh orang lain dan (d) Kepastian, adalah kriteria untuk menilai bermutu atau tidaknya hasil penelitian. Jika dipendabilitas digunakan untuk menilai melalui kualitas dari proses yang ditempuh oleh peneliti. Maka konfirmabilitas digunakan untuk menilai kualitas hasil penelitian sendiri. Dengan tekanan pernyataan "apakah data dan informasi serta interpretasi dan lainnya didukung oleh materi yang ada dalam "audit trail".

\section{HASIL DAN PEMBAHASAN \\ Pelaksanaan pengembangan pendidikan karakter melalui pengelolaan Kantin Kejujuran di SMA Negeri 8 Malang.}

Pendidikan Anti Korupsi/Kantin Kejujuran adalah kantin yang menjual makanan dan minuman. Kantin Kejujuran 
tidak dijaga oleh orang seperti kantin biasa. Makanan dan minuman di pajang dalam etalase dan tersedia kotak uang yang berguna menampung uang pembayaran dari siswa yang membeli makanan atau minuman. Bila ada kembalian, siswa mengambil dan menghitung sendiri uang kembalian dari dalam kotak tersebut. Pendidikan Anti Korupsi/Kantin Kejujuran ini sangat menguji kesadaran siswa, Karena dituntut untuk berbelanja dengan membayar dan mengambil uang kembalian jika memang berlebih tanpa harus diawasi oleh pegawai kantin.

Pendidikan Anti Korupsi/Kantin Kejujuran dipersiapkan sebaik mungkin dan mendapatkan dukungan dari berbagai pihak, Salah-satunya dari Dinas Pendidikan Malang. Kantin Kejujuran adalah kantin yang menjual makanan dan minuman, Semuanya dipajang dalam etalase tanpa ada penjaga, Sebagaimana lazimnya sebuah kantin yang kita kenal selama ini, Di dalam kantin di pajang kotak uang yang berguna untuk menampung hasil transaksi siswa, Bila ada kembalian maka mereka sendiri yang mengambil dan menghitung hasil kembaliannya. Pendidikan Anti Korupsi/ Kantin Kejujuran merupakan upaya sekolah untuk mendidik akhlak siswa agar berperilaku jujur.

Pendidikan Anti Korupsi/Kantin Kejujuran harus di bangun mulai sekarang, dan dikembangkan di lembaga pendidikan, Bahkan diterapkan secara nyata di dalam masyarakat. Pelaksanaan Pendidikan Anti Korupsi/Kantin Kejujuran di SMA Negeri 8 Malang ini sangat penting, Karena mendidik dan melatih siswa untuk jujur dan merubah perilaku siswa yang tidak jujur menjadi jujur. Sehingga dengan demikian dapat menciptakan siswa yang cerdas secara intelektual dan cerdas secara moral (tingkah laku). Pendidikan karakter mempunyai peranan sangat penting dalam pengelolaan Kantin Kejujuran, Karena melalui Kantin Kejujuran ini siswa akan dibentuk karakternya dengan mulai dibiasakan untuk belajar jujur. Hal tersebut terlihat ketika siswa berada di kantin pada saat membeli makanan dan minuman, serta membayar sendiri tanpa ada yang mengawasi.

Pihak sekolah harus bekerja sama dengan keluarga, masyarakat, dan elemen bangsa yang lain demi suksesnya agenda besar menanamkan karakter kepada peserta didik sebagai calon pemimpin bangsa di masa yang akan datang. Guru Pendidikan Kewarganegaraan SMA Negeri 8 Malang tidak hanya mengajarkan materi-materi yang ada dalam Pendidikan Kewarganegaraan, Tetapi guru Pendidikan Kewarganegaraan juga berperan aktif dalam menumbuhkan pendidikan karakter dalam diri peserta didik. Sebuah usaha untuk mendidik anak-anak agar dapat mengambil keputusan dengan bijak dan mempraktikkannya dalam kehidupan seharihari, Sehingga, mereka dapat memberikan konstribusi yang positif pada lingkungannya.

Pendidikan Anti Korupsi/Kantin Kejujuran bertujuan untuk meningkatkan mutu penyelenggaraan dan hasil pendidikan di sekolah yang mengarah pada pencapaian pembentukan karakter dan akhlak mulia peserta didik secara utuh.

\section{Kendala yang ditemukan dalam pelaksanaan pengembangan pendidikan karakter melalui pengelolaan Kantin Kejujuran di SMA Negeri 8 Malang.}

Pendidikan Anti Korupsi/Kantin Kejujuran di SMA Negeri 8 Malang sudah berjalan dengan baik. Namun dalam perkembangannya tidak terlepas dari berbagai kendala yang dihadapi selama berjalannya Kantin Kejujuran.

Pendidikan Anti Korupsi/Kantin Kejujuran di SMA Negeri 8 Malang, yaitu semua siswa belum tentu bisa untuk berbuat jujur, disiplin, mandiri, tertib dan bertanggungjawab. Sehingga pengelola Kantin Kejujuran mengalami kesulitan, dan ini menjadi tantangan SMANegeri 8 Malang. 
Pelaksanaan Pendidikan Anti Korupsi/Kantin Kejujuran di SMA Negeri 8 Malang mengalami kemajuan yang sangat luar biasa, Sehingga sekolah merasa bangga karena sudah berhasil menerapkan kejujuran dalam diri siswa.

Pelaksanaan Pendidikan Anti Korupsi/ Kantin Kejujuran di SMA Negeri 8 Malang mengalami kendala. Karena ada salah satu dari siswa yang tidak jujur dan ini menjadi tantangan sekolah untuk lebih mengawasi, memberikan motivasi dan pembinaan terhadap peserta didik agar selalu berperilaku jujur, Bagi masyarakat dapat mendidik generasi muda berperilaku jujur dan berakhlak mulia. Supaya dengan adanya Pendidikan Anti Korupsi/Kantin Kejujuran ini dapat membangun kehidupan masa depan yang menyampaikan/menyatakan yang sebenarnya dan akurat fakta-fakta yang terjadi pada masa lalu maupun yang akan datang.

Pelaksanaan Pendidikan Anti Korupsi/ Kantin Kejujuran belum maksimal untuk melatih dan menanamkan nilai kejujuran pada diri siswa. Program-program pendukung untuk penanaman nilai jujur yang disediakan sekolah di luar dari konteks Kantin Kejujuran masih kurang. Kesadaran siswa untuk bersikap jujur masih kurang yang dibuktikannya dengan perolehan tingkat prosentase kejujuran yang belum bisa $100 \%$ secara konstan. Dan evaluasi yang dilakukan sekolah untuk bisa meyakinkan siswa untuk bisa bersikap jujur masih kurang.

Kendala yang sangat mendasar dalam Pendidikan Anti Korupsi/Kantin Kejujuran ini adalah kurangnya kesadaran dari siswa itu sendiri. Maupun kurang pengawasan dari pengelola Kantin Kejujuran sehingga siswa seenaknya mengambil makanan tanpa bayar.

Solusi yang dilakukan untuk mengurangi kendala yang ditemukan dalam pelaksanaan pengembangan pendidikan karakter melalui pengelolaan Kantin Kejujuran di SMA Negeri 8 Malang.
Setiap kendala-kendala yang dihadapi tentunya perlu dicarikan solusi, Sehingga Pendidikan Anti Korupsi/Kantin Kejujuran ini dalam perkembangannya dapat berjalan dengan baik dan harapannya dapat membentuk karakter siswa yang jujur.

Memberikan pengarahan melalui upacara yang ditekankan tentang tanggung jawab utama guru dan masyarakat dalam mempersiapkan kader masa depan yang berkualitas di bidang ilmu, moral, mental. perjuangan adalah di mulai dari lembaga pendidikan dan memberlakukan orang lain seperti keinginannya diberlakukan oleh orang lain, menyatakan yang sebenarnya, bermain seperti aturan main, tidak menyalahkan orang lain karena kesalahan diri sendiri, tidak mengambil keuntungan dari orang lain, tidak bertindak berdasarkan favoritisme.

Menjadwalkan tiap kelas supaya menerapkan Pendidikan Anti Korupsi/ Kantin Kejujuran, dengan tujuan jujur dapat dipegang janjinya, tidak pernah berbohong, berkomitmen tinggi untuk menjalankan kebenaran, dan perasaan kedekatan dan saling mengasihi dalam kesatuan dengan orang lain dan mampu melakukan harmonisasi sumber daya yang dimiliki masing-masing sehingga dapat melakukan pekerjaan dengan efektivitas yang maksimal. Solusi yang diambil untuk mengatasi masalah yang muncul, yaitu memberikan peringatan, dorongan atau motivasi agar siswa mau belajar dan berlatih mengimplementasikan nilai-nilai pendidikan karakter seperti kejujuran, keadilan, tanggung jawab, kedisiplinan, ketertiban serta kemandirian.

Pengendalian melalui kontrol buku tamu/buku kunjungan kantin atau melalui CCTV. Setiap dua hari sekali guru atau petugas kantin memeriksa laporan keuangan dan mencocokkannya dengan buku tamu.

Memberikan motivasi, dorongan, pengawasan, perhatian, peringatan, 
kalau melanggar diberi sanksi kepada siswa, Supaya memiliki kemauan untuk menjalankan kujujuran yang ada di sekolah dengan tertib.

\section{SIMPULAN}

Berdasarkan hasil penelitian dan pembahasan yang dilakukan oleh peneliti tentang pengembangan pendidikan karakter melalui Kantin Kejujuran di SMA Negeri 8 Malang. Pendidikan Anti Korupsi/Kantin Kejujuran diluncurkan sekitar 6 bulan yang lalu. Konsepnya sederhana, tempat yang berlokasi di depan ruangan guru SMANegeri 8 Malang. Menyediakan barang dagangan makanan dan minuman ringan, di display di atas meja lengkap dengan label harga, disediakan kotak uang di atas meja yang berguna untuk menampung pembayaran dari siswa yang membeli makanan dan minuman. Bila ada kembalian, siswa mengambil dan menghitung sendiri uang kembalian dari kotak tersebut. Mekanisme pengelolaan diserahkan sepenuhnya kepada siswa, dan dibimbing oleh pengelola Pendidikan Anti Korupsi/Kantin Kejujuran. Kendala yang ditemukan dalam pelaksanaan pengembangan pendidikan karakter melalui pengelolaan Kantin Kejujuran di SMA Negeri 8 Malang (a) masih ada ketidakjujuran. Jumlah uang yang masuk tidak sesuai dengan makanan dan minuman yang terjual. Walaupun tidak banyak dan ini menjadi tantangan SMA Negeri 8 Malang dan (b) tidak disediakan uang kembalian sehingga ada anak-anak yang hutang tapi lupa membayarnya. Solusi yang dilakukan untuk mengurangi Kendala yang ditemukan dalam pelaksanaan pengembangan pendidikan karakter melalui pengelolaan Kantin Kejujuran di SMANegeri 8 Malang, yaitu: (a) memberikan pengarahan dan bimbingan kepada siswa secara terus menerus baik dalam upacara maupun di kelas; (b) intensitas pembimbingan, pengarahan, motivasi, dan evaluasi oleh Wali Kelas perlu ditingkatkan; dan (c) memasukkan materi tentang kejujuran, keadilan, kesederhanaan, daya juang, dan lain-lain pada setiap mata pelajaran.

\section{DAFTAR PUSTAKA}

Arikunto, Suharsimi. 2010. Prosedur Penelitian Suatu Pendekatan Praktis. Jakarta: Rineka Cipta.

Asmani, Jamal Ma'mur. 2012. Panduan Internalisasi Pendidikan Karakter Di Sekolah. Jogjakarta: DIVA Press.

Lexy J. Moloeng. 1989. Metodologi Penelitian Kualitatif. Bandung: Remaja Karya

Margono, S. 1997. Metodologi Penelitian Pendidikan. Jakarta: Rineka Cipta.

Zurial, Nurul. 2009. Metodologi Penelitian Sosial Dan Pendidikan. Jakarta: PT. Bumi Aksara.

Zuriah, Nurul. 2000. Modul Mata Kuliah Penelitian Pendidikan dan Penulisan Karya Ilmiah. Program Akta Mengajar FKIP-UMM Malang. 2014. Undang-Undang Dasar Negara Republik Indonesia Tahun 1945. Jakarta: Sekretariat Jenderal MPR RI. 